\title{
Research on the Development of Early Opera in the Golden Age of the Netherlands
}

\author{
Zhenhua Chang \\ Nanjing Normal University, Wenyuan Road Xianlin University Town, Nanjing 210023, China
}

\begin{abstract}
Different from the general impression of the history of European opera, the early opera activities of the Netherlands do not obviously lag behind the European countries with deep opera cultural traditions such as Italy, France and Germany, but are basically synchronous. The early opera activities in the golden age of the Netherlands were controlled by the market and were known as "free opera". At the same time, based on the needs of local cultural development after the regime change, early Dutch opera works with diverse genres and rich artistic forms have emerged. After the decline of the Dutch Republic at the end of the 18th century, opera activities stopped abruptly and entered a silent period.
\end{abstract}

Keywords: Dutch Opera, Early Dutch Opera, Dutch Golden Age.

\section{The Background of the Development of Early Dutch Opera}

In the rich and prosperous Dutch Republic (also known as the United Republic of seven provinces of Netherlands, 1581-1795), that is, the "golden age of the Netherlands", the early opera activities in the Netherlands were very active. Although the social wealth accumulated to an unprecedented height, because the political system, religious atmosphere and values of the Republic were different from those of European feudal countries at that time, the development characteristics of early Dutch opera were distinct and hidden dangers, which indirectly led to the decline of Dutch classical opera culture in the subsequent historical period.

Before the 16th century, the Netherlands was in a state of feudal separatism for a long time and was ruled by Spain at the beginning of the 16th century. The economic situation, together with some religious and political factors, forced the Netherlanders to openly rebel against Spanish rule. The nature of the Dutch is ancient Germanic, individualistic, instinctively opposed to all the centralized models that forced it to become absolute absolutism. In 1568, due to the resistance to the centralization of power by the king of Spain and the persecution of Protestant Calvinists, the war in the northern province against Spain lasted for 80 years broke out in the Netherlands. In 1579, the seven provinces in northern Netherlands signed a treaty to establish the Utrecht alliance, and the Republic was officially established in 1581. In 1648, Philip IV signed the Treaty of Minster, which recognized the United Republic of the seven provinces of Netherland.

After gaining independence from Spain, the Netherlands developed into a maritime and trade power in the 17th century, reached the peak of commercial prosperity, and became the largest colonial power in the world. The Netherlands had the most powerful navy in the world from 1590 to 1712 . The number of merchant ships exceeded the total number of merchant ships of all European countries. It was known as the "coachman at sea". There are 20000 ships in the world and 15000 in the Netherlands. The West India Company, established in 1621, obtained the trade monopoly of all islands from the west coast of Africa, the east coast of America and between the two continents to the south. Just as the East India
Company regards the Indian Ocean as its internal lake, the West India Company regards the Atlantic Ocean as its private property. The Dutch East India Company has 15000 branches, accounting for half of the world's total trade.

There is no doubt that the Netherlands was the richest and most urbanized place on the European continent at that time. The 17th century is a period of wealth accumulation, and the 18th century is a period of wealth enjoyment. Hundreds of millions of rupiah is still used for foreign trade and commercial activities, in addition to a large amount of surplus funds for speculation. The Republic has a developed monetary and banking system, which has greatly promoted the development of Commerce. Amsterdam established a city bank in 1609. The municipal government provides a deposit for it. The credit and money orders it provided were everywhere, which greatly promoted the development of the Republic's foreign trade. In the 18th century, the Republic became the world's big creditor, and the stock exchange in Amsterdam became the international stock trading center. 340 million rupiah was invested in the bonds of Europe, the East India Company and the Americas. Most of the British government bonds are in the hands of the Dutch.

Compared with the highly developed economic situation, the cultural development of the Republic has not been paid attention to, especially the emergence of public opera activities. Although it appeared as early as the 1630s, almost at the same time as the world's first public opera house in Venice in 1637, it is not essential. Dutch opera was not as prosperous as it was in Italy or soon in France, but was ignored by the "ruling" and "Regent" families of the Republic.

There are few important royal courts in the Netherlands. At that time, the "ruling" orange family was mainly military leaders rather than political authorities. During the period of the Republic, there were many blank periods of governance. The Provincial Parliaments took the opportunity to weaken the power of governance, and the power of the ruling family was even weaker. They will not privately fund the instrumental Orchestra, let alone the opera house, and there is no way to talk about the cultivation of professional musicians. In contrast to the "ruling" family, the "Regent" family, which actually controls the political situation, regards opera 
activities as a profitable business and continues to subsidize public charitable organizations with performance profits, resulting in the lack of funds for long-term development of opera houses and troupes and falling into the shadow of bankruptcy. The "Regent" family, which believes in Protestant Calvinism, even hopes to cancel music in worship. They are also worried about the negative impact of irregular art such as opera, and have always had a lot of opinions on opera.

The religious atmosphere in the Republic is moderate, conservative and pragmatic. In addition to accepting religious persecuted people from all over Europe, the Dutch have also established a large number of hospitals and relief homes for the elderly, the sick and the disabled and orphans. The practical thought made the Dutch lack of strong interest in building churches, but they established many organizations with public characteristics. The supervision of these organizations is in the hands of a group of elderly women and gentlemen who voluntarily engage in charitable services. In the orphanage, orphans learned good trade methods and became useful members of society. For the Dutch, it is the most reasonable way to use the profits from opera activities for religious charities and cultivate trade talents.

The early Dutch opera also had elegant and vulgar differentiation to meet the needs of different groups. In the 18th century, there were about 1.7 million residents in the Republic, which was nominally divided into three parts. The highest is the Regent and the lowest is the ordinary people. Between them are a large number of wealthy and well-educated families who enjoy all the benefits of wealth. Because the general public has not received enough education to entertain themselves with their own thoughts, they often entertain themselves with the noise and play of a group of people. The Regent family hopes to establish local culture and also likes the most popular and popular foreign opera. Wealthy families are well bred and are the main audience of opera. Ordinary people prefer lively song and dance dramas.

The development of early Dutch opera culture also conflicts with the social values at that time. The daily life, mode of thinking and emotional type of the Netherlands Republic can be described as a business community. Omnipotent money is a sign of success. "Good" means the ability to repay debts, and "bad" means the lack of such ability. The measure of culture cannot be so simple and crude. But even under the negative social conditions, the early Dutch opera can develop wonderful works of art, which shows the strong vitality of culture.

\section{Theatre and Troupe in the Situation of Free Opera}

The term "free opera" was first put forward by the managers of Amsterdam theater in the 17th century. They are very welcome to the traveling opera troupes mainly from Italy and France, and do not care whether these groups have their own cultural attributes. Free opera is also quite commensurate with the free trade and religious freedom advocated by the Netherlands Republic.

However, this "freedom" is a double-edged sword. On the one hand, theaters and troupes have relative autonomy in the selection of drama purposes, and can quickly introduce foreign popular operas to participate in competition. The market determines the success of the performance and gives back profits. On the other hand, the church and government authorities will not safeguard the interests of the theater or troupe, let it live and die, and even approve opera performances and return performance profits to form a cycle, which virtually hinders the subsequent development of the theater and troupe. Moreover, in extreme cases, the authorities will close the theater in times of political or other crisis, further reducing "freedom". The development of privately funded opera houses is difficult. After maintaining performances for several seasons, they are closed from time to time, perform intermittently, and often end in bankruptcy.

Failed private investments abound in opera houses. In Amsterdam, for example, Theodore strick organized an opera performance at the new ledsegraht opera house. Under the arrangement of his most powerful assistant, composer Pietro Antonio fioko, consul William III and poet/diplomat Constantine Huygens attended the performance of the opera "Hercules of Dianella" (1680).

Strick got permission from the head of the orphanage and nursing home to develop his Amsterdam opera house. However, the premise of the license was that, according to the practice at that time, the profits of the theater must flow back to the Treasury of the church. Strick was unable to maintain the theatre and had to close his theatre at the end of 1681 .

The private Opera House established by rich businessman Jacob Lopez de Leeds also ended in bankruptcy. He is a Spanish Jew from Portugal. The wealth trust is in the Bank of England, also known as Francisco de Leeds, Jr. He funded the opera house on Langen wahut street in the Hague. The theatre is actually a French style Conservatory of music. The first opera produced was "Tan cred" written by Andre campura in 1719. However, only two seasons later, the theater closed, and musicians took their works to other parts of the city, kasu Ali stratt street. In 1731, Leeds made a second attempt, but the project lasted only a few seasons. The property on Langen wahut street was sold in 1735. In 1743, Leeds declared bankruptcy. The cost of maintaining an opera house in cheap Holland is too high even for wealthy sponsors like de Leeds.

The authorities have also spared no effort in exploiting foreign theatres and song troupes. The troupe set up a tent on the outskirts of Amsterdam. Buixlo area on the North Bank of the water river was not under the jurisdiction of the Regent of Amsterdam, and the troupe built a performance house here. However, the local authorities still shared the profits with the local council for the construction of downpipes for churches.

The authorities have also spared no effort in exploiting foreign theatres and song troupes. The troupe set up a tent on the outskirts of Amsterdam. Buixlo area on the North Bank of the water river was not under the jurisdiction of the Regent of Amsterdam, and the troupe built a performance house here. However, the local authorities still shared the profits with the local council for the construction of downpipes for churches.

During the period of the Republic of the Netherlands, the 
development process of early Dutch opera was basically consistent with the latest trend in Europe, sometimes even slightly ahead. The latest and best foreign works have also been quickly staged. For example, the public theater appeared in 1634, and Jane harmenszon kruer established a music room in Amsterdam. This is an association that discusses the relationship between music and drama and occasionally holds performances. Compared with the Venice public theater established in 1637, the Dutch public theater was founded quite early. From 1638 to 1772 , some opera works were occasionally performed in Amsterdam theater near the emperor canal in Amsterdam, including the works of some Dutch composers. For example, on January 5, 1677, Luli's Opera Isis was premiered at Saint Germain castle on the outskirts of Paris. In the following months, the opera was quickly staged in the Amsterdam theater.

In the Hague, the development of the opera house should be slightly stable. Due to the need of diplomacy, there are many French works. In 1681, the city government of the Hague suggested that French opera works be performed in a small theater located in casuali street. From then on until 1804, the latest opera works produced by the Paris Opera House can be seen in the Hague. There are 20 people in the symphony orchestra. Since then, some short opera works, including works in German, Italian or Flemish, began to be performed frequently in this theater.

Foreign touring theatres began in Amsterdam and the Hague. They also performed operas in Harlem, levaarden, Rotterdam, Maastricht, Utrecht or Arnhem from time to time. Subsequently, the French opera company, the Italian opera company and the local Dutch opera company settled in Amsterdam and maintained a long-term performance. The German opera company came late and finally occupied a place.

During the eighteenth century, Amsterdam had a French opera company, an Italian opera company and a Dutch opera company. It was the home of three opera companies. The vulgar song and dance performances performed in Dutch are very different from the opera as a luxury of the middle class. At the same time, the upper class loved the latest box office opera works abroad, so that the audience in Amsterdam could enjoy the latest operas from Vienna, Prague and Paris. Local opera groups compete with each other to stage the latest works of Gluck and Mozart as soon as possible.

Dutch groups appeared at the Amsterdam theater near the emperor canal. For more than 25 years since 1774, the music director of the theater, horomes rulovs, devoted himself to improving the standards of local works and foreign imported works. He translated operas and singing dramas into Dutch and paid attention to new Dutch works. He wrote a new movement for the 17th century popular comic work "the wedding of Chris and Ross". His work Zemel and Azor, created in 1784, was a great success. He also composed music for the successful singing drama Richard I of England (1792). After years of efforts, he expanded the orchestra of the theater from 16 to 30 .

At the same time, the French group in Amsterdam used the Vaux hall in otom for the first time, and moved to its own theater as the "Academy of drama and music" in 1786, which is located in the pea market near amsdirkad. The theater, now called Xiaoxi theater, is still used to perform cabaret songs and dances. Here, mainly French musicians and actors, perform operas created by French composers gretley, Mehul and Cruze, or works translated into French created by German and Italian composers.

In 1791, the German opera house opened in nearby amsdir street, performing stage plays and operas at the same time. His works include the pharmacist and doctor by the Austrian composer Carl de Stetz von ditsdorf and the temptation of the harem by Mozart (the first Mozart opera performed in the Netherlands).

The houduiz opera house in Amsterdam introduced Mozart's opera to the audience. In 1794, the amsdir street theatre also staged German versions of Don Juan and Figaro's wedding, just like the Magic Flute and the escape of the harem. Amsterdam people even saw Don Juan earlier than the audience in Paris and London! From 1798 to 1801, soprano Louise Langer was the first female chief executive of the houduitz opera house, where she participated in three seasons. In addition to her brother-in-law Wolfgang amadoys Mozart, she also participated in other performances.

At the end of the Dutch Republic, the ruling returned to the orange Dynasty. Prince William IV of frisland and his wife Princess Anna of the British Hanover Dynasty loved music, but the ruling family mainly rented private boxes to support the French theater in the Netherlands for court entertainment. William IV died in 1751. From the Regency of his wife (to 1759) and the court of Duke Ernest van Brunswick (to 1766), until William $\mathrm{V}$ reached the age of 18 and took over the position of Regent, the court continued to pay the French theater for watching the performance.

During William V's term of office, opera occupied a more prominent position in the agenda of the ruling family. Although William and his sister Carolina had English upbringing, were related to Germany, and William V's wife was Princess William Minna from Prussia, the court at that time still indulged in French culture. But even so, the orange dynasty did not follow the custom of maintaining Court Opera in France, but purchased a large number of opera performance services. In this way, they indirectly supported Albert, the French theatre, the Dutch theatre, the Italian and Flemish song theatre until the court's budget could not sustain such expenditure in 1787. Due to the political tension at that time, the court regarded opera as unnecessary extravagance and waste.

\section{Dutch Opera Works}

The operas first performed on a large scale on the Dutch opera stage are basically performed in Italian, German, French and other original languages. Occasionally, the French version may be used. Its original works are still created in Italian and German. There are few opera works created in Dutch, and the localization of opera language and theme in the Netherlands is limited.

Until the 18th century, more and more foreign opera houses 
went to the Netherlands to present a variety of operas. Audiences eager for opera are becoming more and more familiar with opera seria and opera buffa, and they are also familiar with tracedie lyrique and opera Comique in France. Occasionally, these operas are sung in the original text, but more often they are sung in translated Dutch. In this regard, for pragmatic reasons, neither the performers nor the audience are particularly tangled: many Italian operas are performed in French, Dutch or German, depending on which country the opera house comes from.

Due to the lack of continuous music sponsorship and the indifference of Dutch composers to opera in the general sense, the development of Dutch opera is slow. Although the ruling family is still closely connected with French culture in cultural psychology, the Regent class is more concerned about the cultural development of the Netherlands. Among them, intellectuals and artists even become the direct creators of early Dutch opera or semi opera works, writing stories and scripts and composing operas. Opera themes also include pastoral poetry, mythological drama, Dutch historical events and so on.

Pieter cornelisz Hooft's stage play granida is considered to be a real theater musical and can be regarded as a precursor of early Dutch opera. Granida, an idyllic poem originally belonging to a genre model in Dutch literature, tells the love story between Persian Princess granida and shepherd daphilo. The story was adapted into a stage play. Throughout the 17th century, granida performed frequently and achieved great success. Granida is just one of many performances with songs and instrumental interludes, which are far more popular than works from traveling opera houses in France or Italy.

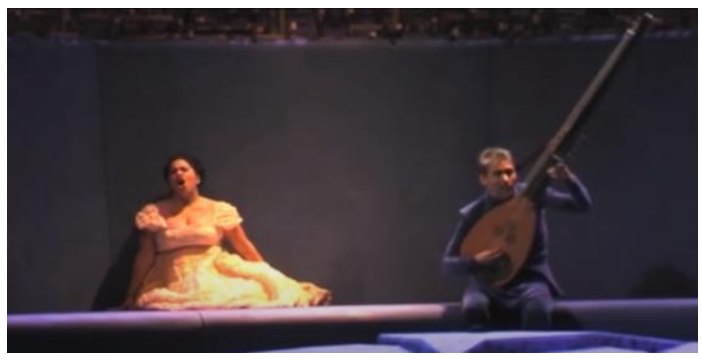

In 1678, Dirk buysero and Carolus hacquart created a semi opera work, de triomfeerende min. Although this work is more like a singspiel, it has a great impact on the later music development. Its story is based on the major events in Dutch history in the same year to celebrate the successful signing of the Treaty of Nijmegen. Compared with the previous themes based on Greek mythology or historical events in other countries, the difference is that this theme really belongs to Dutch culture itself. After the signing of the treaty, the Dutch Republic really gained its independent status and became one of the world powers.

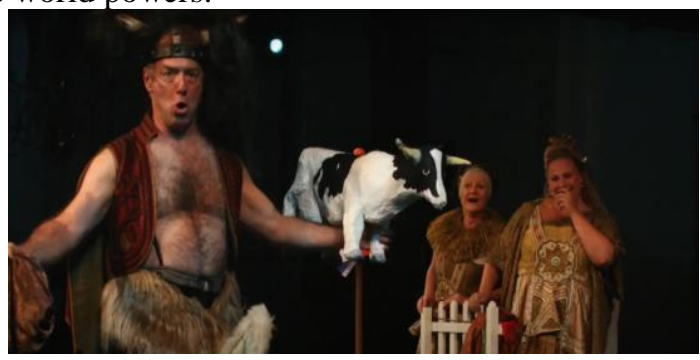

In 1686, Amsterdam staged the first real opera Bacchus, Ceres en Venus in the modern sense. The script is written by the Regent, physician and government bidloo of Amsterdam, and the composer is Johann Schenck. In fact, the opera has no oral lyrics, just a narrator. The Dutch public loves to mix a lot of music in stage performances.

The story depicts the quarrel between the gods. Ceres and Bacchus decided to avoid Venus. Mercury, the messenger of Cupid, intervened, and finally restored the harmony of love, wine and rich products. The performance was a great success, with 12 performances. In the early stage of performance, the open way of performance had an impact on the psychology of the old-fashioned Calvinist audience. Venus is played by a naked female singer, and many dances on the stage depict Bacchus and his sexy attendants. The combination of Dutch opera and stage nudity is older than the Salzburg Festival.

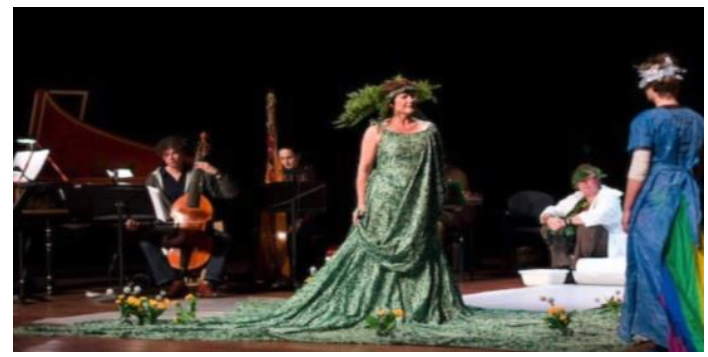

Zemire et Azor, created by Bartholomeus ruloffs, music director who has worked in Amsterdam theater since 1774, is also a semi opera work, which is regarded as a musical mixed with ballet performance. The play is one of the most successful and popular works in the 18th century. It has won box office success and has been staged 13 times. Lulovs composed music for a Dutch script adapted from French. The story tells of an old businessman picking roses in a terrible blue garden. The monster guarding the garden blamed him and needed one of his three daughters to make up for the mistake.

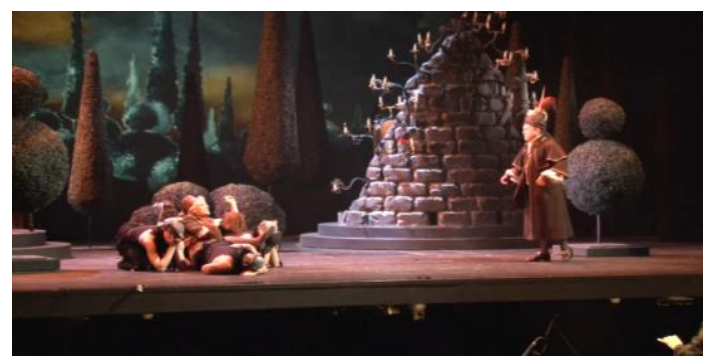

\section{Summary}

In 1795, the Netherlands was occupied by France and established the Batavia Republic, the puppet government of the first Republic of France. So far, the Dutch Republic has completely declined. Before the military defeat, the prosperity of the Republic gradually and slowly disappeared, partly due to changes in the economic situation and mainly due to changes in the character of the people. It is a slow, almost imperceptible process for decades. With the disappearance of the Republic, the development of early Dutch opera stagnated. Since then, more than 100 years before the formal establishment of the Dutch National Opera House in 1964, the Dutch classical opera fell into a trough, and the modern opera was not developed until the contemporary era. 
Although the Dutch Republic has enjoyed nearly 200 years of rich life, the development of opera in the early golden age has already buried hidden dangers. Due to the lack of long-term and stable capital investment and strong support at the national level, as well as the accompanying lack of training for professional musicians, Dutch script writers, especially composers, there is a further lack of music talents. The follow-up development of Dutch opera is weak, so we have to follow the pace of opera development in other countries.

\section{References}

[1] S.A.M. Botterheim, De opera in Nederland, 2nd revised edition by Peter Wander (Leiden, 1983).

[2] Leo Samama, Nederlandse muziek in de 20ste eeuw. Voorspel tot een nieuwe dag (Amsterdam, 2006)

[3] Henk Suer en Josine Meurs, Geheel in de geest van Wagner. De Wagnervereeniging in Nederland 18831959 (Amsterdam, 1997)

[4] Aart Bouwmeester, Opera in uitvoering. Operaproduktie in Nederland (Kunst in bedrijf; 1), (Amsterdam 1990)

[5] Tim Coleman et al.(red.), Een noodzakelijke luxe. 15 jaar Nederlandse Operastichting, 1971/1986, (Amsterdam/Zutphen, 1986)

[6] Ministry of Cultural Affairs, Recreation and Social Welfare, Opera en ballet in West- Europa en NoordAmerika. Verslag van een studie naar opera, ballet, muziek omroep en overheidsbeleid in Londen, Wenen, Frankrijk, West- Duitsland, New York en Toronto (The Hague, 1911)

[7] De opera in Nederland, Rapport van de Onderafdeling Opera en Dans van de Raad voor de Kunst inzake de ontwikkeling van de muziekdramatische kunst in Nederland (The Hague, 1962)

[8] Werkgroep Operavoorziening, Interimrapport landelijk operabestel (Rijswijk, 12 October 1976)

[9] Frederique van Cleeff-Hiegentlich and Joel Cahen, Waterlooplein. From Commerce to Culture in Four Centuries (Amsterdam, 1987)

[10] S. Herweijer, Rapport van de Commissie Stadhuis/Muziektheater. Onderzoek van de financiele situatie rondom de bouw van het Stadhuis/ Muziektheater (Gemeenteblad bijlage P, Amsterdam, 1988)

[11] Max van Rooy and Bas Roodnat, De Stopera. Een Amsterdamse geschiedenis (Amsterdam/Brussels, 1986) Zou Benchu: Singing - A Study of Shen Xiang's Singing System[M]. Beijing, People's Music Publishing House, 2000, 56-57.

[12] Ye Songrong. History of Western Music[M]. Beijing: Higher Education Press, 2003.

[13] H.W. Vanloon. History of The Rise and Fall of the Dutch Republic[M]. Hebei: Hebei Education Press, 2002. 